\title{
SPORTOLÓ ÉS NEM SPORTOLÓ FIÚK REGIONÁLIS ZSÍRELOSZLÁSÁNAK MINTÁZATA
}

\author{
Pápai Júlia ${ }^{1}$, Négele Zalán $n^{2,3}$ és Tróznai Zsófia ${ }^{1,3}$ \\ ${ }^{1}$ Testnevelési Egyetem, Teljesítmény-élettani Laboratórium, Budapest; ${ }^{2}$ Székesfehérvári Teleki \\ Blanka Gimnázium és Általános Iskola, Székesfehérvár; ${ }^{3}$ Testnevelési Egyetem, Sporttudományok \\ Doktori Iskola, Budapest
}

Pápai J., Négele Z., Tróznai Zs.: Regional fat pattern of athlete and non-athlete boys. The study deals with the connection between sexual maturation and fat accumulation during male puberty. The purposes were: (1) to follow the alterations in regional body adiposity during genital development; (2) to reveal the differences in fat patterning of athletes and non-athletes, (3) to analyze the influence of genital maturation and sport activity on the indices of fatness in pubertal boys. The subjects were athlete $(n=803)$ and non-athlete $(n=989)$ boys. They were grouped by the stages of genital development. Regional fat distribution was examined on the basis of skinfolds. The amount of subcutaneous and visceral abdominal adipose tissues was assessed by regression equations of Brambilla and co-workers. The effect of genital development and sport activity on fat compartments was studied by multivariate ANOVA.

The centralization tendency in adipose tissue was revealed by the progressing of genital development. Non-athletes accumulated more relative subcutaneous fat on their extremities, while athletes did it on their trunk. Adjusted to the absolute body fat mass, visceral adipose tissue increased faster in athletes than in non-athletes. The multivariate model proved that genital maturation affected the regional fat distribution.

During sexual maturation the regional apposition trend of body fat was similar for athletes and non-athletes. The differences between athletes' and non-athletes' fat pattering emerged in the relative distributions. The relatively thicker fat layer on the trunk served better the extended energy supply for athletes. The effect of sexual maturation was the largest on the visceral adipose tissue, while sport activity influenced the subcutaneous adipose tissue better on the extremities.

Keywords: Genital maturation; Regional fat distribution; Athlete and non-athlete boys.

\section{Bevezetés}

A zsírszövet egyik alapvető funkciója a szervezet számára szükséges energia tárolása. Ez az energia részben az életfolyamatok végzéséhez használódik fel, részben mindennapi és extra tevékenységeinkhez szolgáltatja a fütőanyagot. A növekedés során felhasznált energia szintén a zsírsejtekben felhalmozott zsírcseppekbe van becsomagolva.

A zsírszövet nem csupán tároló feladatot lát el, hanem a müködés szempontjából aktív szövetnek tekinthető. Endokrin funkciója mellett kulcsszerepet játszik az anyagcserefolyamatok egyensúlyának fenntartásában, többek között a glükóz, a zsírsavak és a koleszterin metabolizmusában (Malina és Bouchard 1991, Trayhurn és Beattie 2001, Wells 2012, Wronska és Kmiec 2012).

A zsírszövet nem egyenletesen oszlik meg a testen. Több mint háromnegyede a bőr alatt helyezkedik el, és csak mintegy 20\%-a található a test egyéb anatómiai helyein (pl. a 
mellkas-, has-, medenceüregben, az izmok között vagy a csontvelöben; Malina és Bouchard 1991, Shen és mtsai 2003).

A test különböző régióiban elhelyezkedő zsírszövet mind szerkezetileg, mind metabolikus tulajdonságaiban jelentősen különbözik (Arner 1995, 1997, Sbarbarti és mtsai 2010, Wronska és Kmiec 2012). Lipolitikus aktivitását tekintve a fartájékon és a combon található szubkután zsírszövet (gluteofemorális régió) jobban ellenáll a zsírbontó hatásoknak, inkább a zsír raktározására hajlamos. Az abdominális szubkután területeken ez a hajlandóság közepes, míg a legnagyobb zsírbontó aktivitása föleg a törzs üregeiben, a szervek körül elhelyezkedő zsigeri vagy viszcerális zsírszövetnek van (Arner 1995, 1997, Kelley és mtsai 2000, Blaak 2001).

A regionális különbségek sajátos jelentőséggel bírnak. Amikor a szervezetnek hirtelen jelentős energiaellátásra van szüksége, mint pl. fizikai aktivitás esetében, az energiát a gyorsan mobilizálható viszcerális zsírszövet szolgáltatja (Arner 1997). A zsigeri zsírszövet könnyen lebomlik és fel is épül, ezáltal mihamarabb tud alkalmazkodni a szervezetet ért extra megterhelésekhez.

Ugyanakkor nagymérvü felszaporodása tartósan nem kívánatos, mert a szabad zsírsavak és más anyagcseretermékek nagy mennyiségének a vérbe bocsátásával megterheli a keringési rendszert és a közti anyagcserét, ezáltal hozzájárul a keringési, daganatos és anyagcsere betegségek kialakulásához és fenntartásához.

Különösen az ún. android vagy közismert nevén az alma típusú elhízás jelent veszélyt, mert ilyenkor a hormonális hatásokra szenzitíven reagáló viszcerális és szubkután abdominális zsír halmozódik fel túlzott mennyiségben (Kelley 2000, Blaak 2001, Goran és Gower 1999). Ez a fajta elhízás elsősorban a férfiakra jellemző, de előfordul a posztmenopauzális státusban lévő nőknél is. Az adatok azt is bizonyítják, hogy nem elsősorban a test teljes zsírtartalma, hanem inkább annak regionális megoszlása felel a metabolikus és szív- érrendszeri betegségekért (Arner 1995, 1997, Daniels és mtsai 1999).

A körte típusú vagy gynoid elhízás esetében a többlet zsírszövet elsősorban a gluteofemorális tájékra rakódik. Az e területen lévő zsírszövet nehezebben mobilizálható, így védő funkcióval rendelkezik az előbb említett betegségek ellen (Karastergiou és mtsai 2012). A körte típusú elhízás főleg a nőkre jellemző.

A szubkután zsírszövet életkori változása és nemek közötti különbsége a humánbiológiai irodalomban kellően dokumentált (Falkner 1975, Forbes 1978, Malina és Bouchard 1991, Taylor és mtsai 1997, Bodzsár 2001, 2003, He és mtsai 2004, Wells 2010). A nemi különbségek a regionális megoszlásban is jól megfigyelhetők (Arner 1995, 1997, Norgan 1997, Blaak 2001, Manolopoulos és mtsai 2010, Wells 2010, 2012).

A pubertáskornak mindkét nemre jellemző eseménye a zsírszövet átrendeződése, azaz arányaiban egyre inkább a törzsre történő halmozódása (Mueller 1982, Goulding és mtsai 1996, Lenthe és mtsai 1996, Pápai és mtsai 2012). A gyermekkorban még végtagi túlsúlyú zsírszövet csak a pubertást követően válik/válhat törzsi túlsúlyúvá.

A tapasztalatok azt mutatják, hogy a szexuális érés befolyásolja mind a teljes test zsírtartalmát, mind a különböző anatómiai helyeken megtalálható szubkután zsírszövet vastagságát (Garn és mtsai 1986, Lenthe és mtsai 1996, Guo és mtsai 1998, Ribeiro és mtsai 2006, Benfield és mtsai 2008, Pápai és mtsai 2012).

A törzs üregeiben, a belső szervek körül elhelyezkedő zsírszövet vizsgálata in vivo csak képalkotó eljárások segítségével történhet. A felnőttekre vonatkozó óriási adathalmaz az elhízott emberek morfológiai és anyagcsere jellemzőinek kapcsolatát 
vizsgáló kutatások eredményeinek köszönhető. A klinikumban használt módszerek tömeges vizsgálatok esetén azonban nem alkalmazhatók, ezért a zsigeri zsír fejlödésével kapcsolatos kutatások száma nem túl nagy és az eredmények is meglehetősen ellentmondásosak.

Bár a legtöbb tanulmány hangsúlyozza az antropometriai mutatók felhasználásának elégtelenségét, a kutatók testméreteket tartalmazó regresszió-egyenleteket is kifejlesztettek a viszcerális zsírszövet becslésére. A legtöbb egyenlet a felnőttekre alkalmazható (Despres és mtsai 1991, Chen és mtsai 2014, Kekes-Szabo és mtsai 1994, Scafoglieri és mtsai 2014). Készült néhány egyenlet prepubertás- ill. pubertáskorú egészséges fiatalokra (Goran és mtsai 1998, Brambilla és mtsai 2006), valamint túlsúlyos és elhízott gyermekekre is (Owens és mtsai 1999). Bonora és munkatársai (1995) szerint a bőr alatti zsírszövet viszonylag biztonságosan becsülhető antropometriai méretekböl, a zsigeri zsírszövetet azonban csak direkt módszerekkel lehet vizsgálni.

Keveset tudunk a zsigeri zsírszövet gyermek- és serdülőkori változásáról. Jelenleg tisztázatlan, hogy gyermekkorban milyen mennyisége és aránya lenne kívánatos, vagy pl. hogy nagymérvủ felszaporodása összekapcsolódik-e a teljes testzsír extrém mértékével. Néhány tanulmány azt sugallja, hogy gyarapodása arányos a testzsír emelkedésével (Goran és munkatársai 1995) míg mások azt találták, hogy pl. az elhízott gyermekek inkább a bőr alatt, mintsem a belső szervek között hajlamosak több zsírszövetet felhalmozni (Fox és munkatársai 1993).

A zsigeri zsír kora gyermekkorban kezd gyarapodni, növekedési ütemét és átlagos mennyiségét a vizsgálatok többsége közel hasonlónak találta (Ridder és mtsai 1992, Goran és mtsai 1995, Owens és mtsai 1999, Goran és Gower 1999). Huang és munkatársai (2001) eredményei szerint a prepubertásban intenzíven gyarapodó viszcerális abdominális zsírszövet növekedési rátája az életkorral lassul. Jellemző, hogy az egyének közötti varabilitása már gyermekkorban is rendkívül nagy (Fox és mtsai 1993, Goran 1999, Goran és Gower 1999, Goran és mtsai 1995, Ramos-Ibanez 2009). A pubertás idején történő gyarapodásáról szintén ellentmondóak az adatok. Egyesek e zsírkompartment mennyiségének emelkedését találták (Huang és mtsai 2001, Mitova és Mladenova 2014), míg mások stagnálást tapasztaltak (Brambilla és mtsai 1994, 1999, 2006). A fiúk több viszcerális zsírt halmoznak fel, mint a leányok (Goran és Gower 1999, Benfield és mtsai 2008).

Obez gyermekeknél és serdülöknél nemcsak az általános elhízást mutató testtömegindex (BMI) vagy zsírszázalék emelkedett, hanem a regionális zsíreloszlás is megváltozik. A kutatások szerint, ha ez túlhalad egy küszöböt, akkor a normál fejlődési minta nagy valószínüséggel patogén irányba indul, ami egyértelmủen betegségkockázati tényezőnek tekinthető (Kelly és mtsai 2014). A zsírszövet megemelkedett mennyisége szorosan kapcsolódik a szív- és érrendszeri betegségek kockázatával (Gutin és mtsai 2007), míg a bör alatti és a viszcerális abdominális zsírszöveti túlsúly a lipid státus és az inzulinrezisztencia rizikófaktora lehet a szív és érrendszeri kockázat mellett (Kelly és mtsai 2014).

A fizikai aktivitás hatása a szubkután zsírszövetre hasonló ahhoz a trendhez, amelyet a nem sportoló gyermekpopulációkban találtak a kutatók (Malina és Bouchard 1991, Eisemann és Malina 2002), csak a rendszeresen sportoló fiataloknak kevesebb a zsírszövetük, mint az ugyanolyan korú nem sportoló kortársaiknak (Pápai és munkatársai 2012, Tróznai és Pápai 2005). 
A fizikai aktivitás viszcerális zsírszövetre gyakorolt hatását nehéz értelmezni, mivel eddig elsősorban elhízott emberekre vonatkozó adatok láttak napvilágot. Felnőttekben kimutatták, hogy a kellő gyakoriságú és intenzitású tréning egyértelmüen csökkentette a testtömeget, a bör alatti és a viszcerális zsírszövetet (Slentz és mtsai 2009). Treuth és munkatársai (1998) elhízott leányokat vizsgálva megállapították, hogy bár a testtömeg és a bőralatti zsírtömeg a tréning alatt tovább növekedett, a zsigeri zsír változatlan maradt. Owens és munkatársai (1999) szintén kövér fiataloknál intenzív tréning után azt találták, hogy a viszcerális zsír mennyisége lényegesen lassabban növekedett, mint a kontroll gyermekeknél. Kay és Singh (2006) áttekintése szerint kevés az az eredmény, amely a képalkotó eljárások segítségével a fizikai aktivitás pozitív hatását túlsúlyos és kövér embereknél bizonyítaná. Sportoló fiatalokra vonatkozó vizsgálatot e tárgyban nem találtunk. A viszcerális zsír mennyiségének életkori változásáról, befolyásoló tényezőiröl keveset tudunk. Nagy szükség lenne arra, hogy gyermekeknél vizsgáljuk a kölcsönhatást a szexuális érés, a zsíreloszlási mintázat, a táplálkozás és a fizikai aktivitás között.

Célkitüzéseink a következők voltak:

1. A regionális zsírszövet gyarapodásában bekövetkező változások megfigyelése a genitális fejlődés ideje alatt.

2. A sportoló és nem sportoló gyermekek zsírfelhalmozásában kimutatható különbségek elemzése.

3. A genitális fejlődés és a sporttevékenység hatásának vizsgálata a zsírosság mérőszámaira.

\section{Vizsgált személyek és alkalmazott módszerek}

Vizsgált személyek

A sportoló gyermekekre vonatkozóan 2002 és 2008 között Budapesten és az ország nagyvárosainak sportklubjaiban és sportiskoláiban gyüjtöttük keresztmetszeti adatokat (N=803). Életkoruk 9,5 és 16,5 év között változott. Az alminta sportági megoszlását tekintve a gyermekek 40\%-a labdajátékos volt, 35\% aerob sportágakat képviselt (atlétika, úszás, kajak-kenu, kerékpár), 15\% küzdősportot üzött. A minta kb. 10\%-át az egyéb sportágak adták. A sportolók heti edzésideje minimum 4 óra volt.

A nem sportoló fiúk egy 2003 és 2006 között végzett regionális keresztmetszeti vizsgálat képviselői. A jászsági alminta 989 föből állt, életkoruk 9,0 és 15,5 év között volt. Ebben a csoportban a fiatalok csak a testnevelés órákon vettek részt, egy részük alkalmanként rekreációs tevékenységet is végzett.

\section{Alkalmazott módszerek}

A testmérés során hosszúsági, szélességi, kerületi és bőrredő méreteket vettünk fel (Martin és Saller 1957/1966, Tanner és mtsai 1969, Bodzsár és Zsákai 2004). A bőr alatti zsírszövet regionális megoszlásának jellemzésére az elemzésbe nyolc bőrredőt (tricepsz, alkar, lapocka, mellkas, has, csípő, comb, alszár) vontunk be. A testet két-két bőrredő képviseletével négy testtájra osztottuk (felső és alsó végtag, mellkasi és medencei törzsrégió). A proporcionális testtáji zsírszövet vastagságát a vizsgált redők összegének arányában fejeztük ki. Ugyancsak ezen bőrredők felhasználásával elemeztük az egyes testtájakon a zsírszövet egymáshoz viszonyított változását (a felső/alsó végtag = végtagindex, a mellkas/medence = törzsindex bőrredő arány, ill. a törzs/végtag arány is). 
Brambilla és munkatársai (2006) regresszió-egyenleteinek felhasználásával becsültük a bör alatti és a zsigerek közötti abdominális zsírszövet mennyiségét.

A különböző regionális zsírszövet frakciókat kifejeztük a teljes zsírtömeg arányában, hogy a genitális fejlődés során mutatott változási irányukat összehasonlíthassuk.

A testösszetétel komponenseit Drinkwater és Ross (1980) antropometriai módszere alapján számítottuk. Tanulmányban a zsírszázalék és a zsírtömeg adataira támaszkodunk.

A szexuális érés indikátorai közül a genitális fejlődés stádiumai (G1-G5) mentén vizsgáltuk a test zsírszövetének változását (Tanner 1962). A genitáliák fejlettségi szintjét megtekintéssel vizsgáltuk.

A regionális zsírmegoszlási mutatók genitális stádiumok közötti különbségeit egyszempontos varianciaanalízissel vizsgáltuk. A sportolói és nem sportoló csoportokat kétmintás t-próbával hasonlítottuk össze. A sporttevékenységnek és a genitális fejlődésnek a zsírossági mutatókra gyakorolt hatását többváltozós varianciaelemzéssel elemeztük.

\section{Vizsgálati eredmények}

Célkitüzésünknek megfelelően a testösszetételi változások közül a testtáji zsírmegoszlás mintázatát vizsgáltuk meg a szexuális érés folyamatában.

$\mathrm{Az}$ 1. ábra a testzsírtömeget ábrázolja a genitális fázisok szerinti elrendezésben. A sportolóknál a zsírakkumulációban a G1 és G2, valamint a G4 és G5 fázisok között található szignifikáns gyarapodás. A nem sportolóknál a G1-G3 fázisok között intenzív emelkedés, ezt követően stagnálás figyelhető meg. Mindkét csoport valamivel több, mint 3 kg zsírt gyüjtött a vizsgált intervallumban.

Amint az a 2. ábrán látható, a testzsír tömegbeli aránya enyhén növekedett a gyermeki és az első puberális fázis között, majd csökkent egészen a felnőtt fokozat eléréséig. A megközelítőleg 1\%-nyi emelkedést mintegy 3\% körüli csökkenés követte. A tendencia és a változás mértéke mindkét alcsoportban, a sportoló és nem sportoló fiúk csoportjában, hasonló volt. A legnagyobb mérvű csökkenést a genitális fejlődési stádiumokban lehetett megfigyelni (G2-G4). A sportolóknál szignifikáns különbséget a G2-G3, a nem sportolóknál a G3-G4 fokozatok között találtunk. Az ábra azt is jól mutatja, hogy a sportolók és nem sportolók között mintegy 4\%, igen jelentős zsíraránybeli különbség van.

Mivel elsődleges energiaraktárnak a törzsön/törzsben lévő zsírszövet tekinthető (Norgan 1997), érdekes lehet megvizsgálni, hogy vajon a bemutatott változások minden testtájra érvényesnek tekinthetők-e. Feltételezhetjük, hogy a sportolóknál a zsír mennyisége, aránya és változása optimálisabb, mint a nem sportolóknál.

A következő ábrák a bőr alatti zsírszövet testtáji megoszlásának változását mutatják a genitális fejlődés függvényében. A felső végtagon (3. ábra) a zsírarány mind a sportolóknál, mind a nem sportolóknál folyamatosan csökken. Szignifikáns különbség a nem sportolók esetében a G1 és G2 stádium között, majd mindkét alcsoportban a serdülés középfázisában (G3-G4) figyelhető meg. A változás a teljes korintervallumban mintegy 4-5\%, ebböl kb. 3\% a G3 szakasz után tehető. A sportolók és nem sportolók zsírszövetének relatív vastagsága minden genitális stádiumban jelentősen különbözik, a nem sportolók felső végtagján arányaiban kb. 2\%-al vastagabb a bőr alatt felhalmozott zsír.

$\mathrm{Az}$ alsó végtagon (4. ábra) proporcionálisan jóval vastagabb a zsírszövet, mint a felsőn (az eltérés több, mint 10\%), de a változás tendenciája ugyanaz, mint a felső végtag esetében. A sportolóknál a teljes intervallumban kb. 5\% a csökkenés. Az eltérés csak a G4 és a G5 fázisok között jelentős. A nem sportolóknál nincs különbség az egymást 
követő genitális stádiumok között. A bör alatti zsírszövet vastagsága az érés idején mintegy 3\%-ot csökken. A két minta csak a késői pubertásban különbözik (G4-G5), és itt is a nem sportolóknál nagyobb az érték. Mindez azt jelzi, hogy a nem sportoló gyermekek arányaiban jelentősebb zsírtartalékokkal rendelkeznek a végtagjaikon, mint a sportolók.

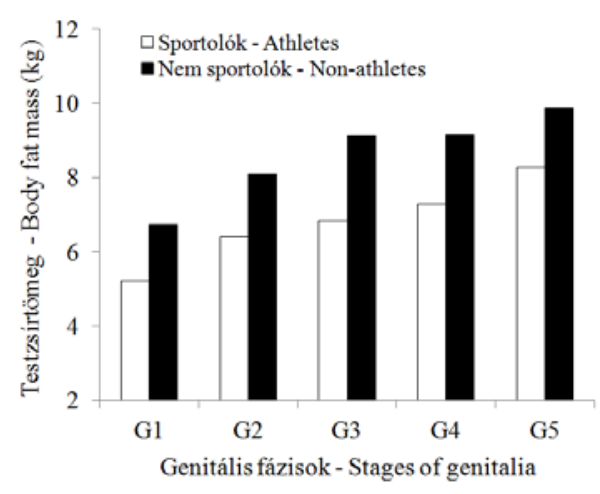

1. ábra: Az átlagos abszolút zsírtömeg a genitális fázisok szerint.

Fig. 1: Mean total body fat mass by the stages of genitalia.

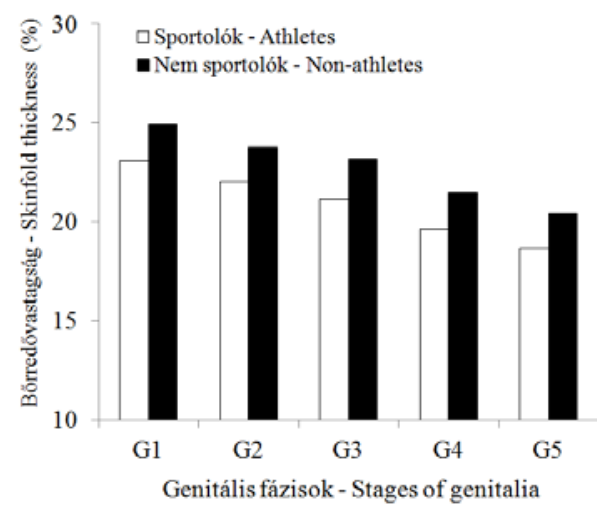

3. ábra: Átlagos relatív bőrredővastagság a felső végtagon.

Fig. 3: Mean relative skinfold thickness on the upper extremity.

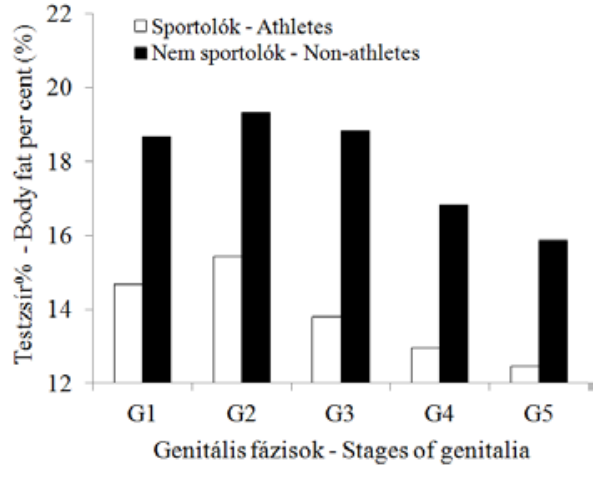

2. ábra: Az átlagos relatív zsírtömeg a genitális fázisok szerint.

Fig. 2: Mean fat per cent by the stages of genitalia.

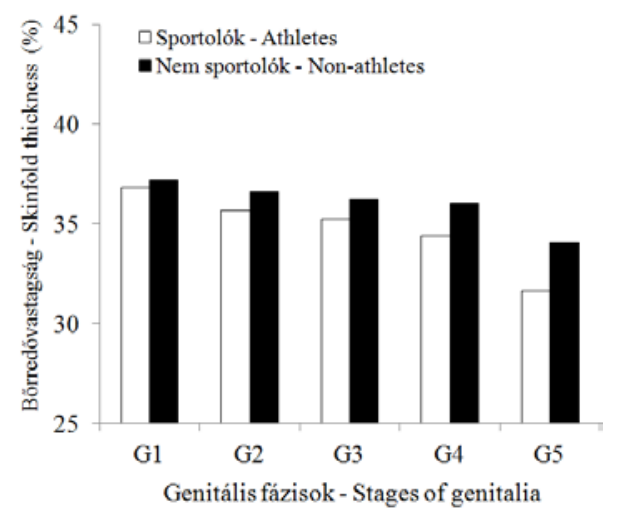

4. ábra: Átlagos relatív bőrredővastagság az alsó végtagon.

Fig. 4: Mean relative skinfold thickness on the lower extremity.

A törzset borító zsírszövet esetében a trend fordított. A mellkason (5. ábra) a genitális fejlödéssel egyidejủleg a zsír felhalmozása figyelhető meg. A változás mintegy $4 \%$. Jelentős emelkedést a G4 és G5 stádiumok között találunk, a növekmény fele erre a szakaszra esik. A sportolók és nem sportolók között ebben az esetben is a posztpubertásban van szignifikáns különbség, a sportolóknak arányaiban több a bör alatt felhalmozott zsírszövetük.

A törzs alsó régiójában (6. ábra) mintegy 8-10\%-al vastagabb a bör alatti zsírszövet, mint a felsőn. Az éréssel elörehaladva határozott gyarapodási tendencia figyelhető meg 
mindkét csoportban. A sportoló és nem sportoló fiúk között a különbségek a genitális fejlődés kezdetén (G1-G2) és végén (G4-G5) a legnagyobbak. A fejlődési stádiumokat tekintve a medencerégióban a sportolók lényegesen nagyobb arányban halmoznak fel zsírt, mint a nem sportolók.

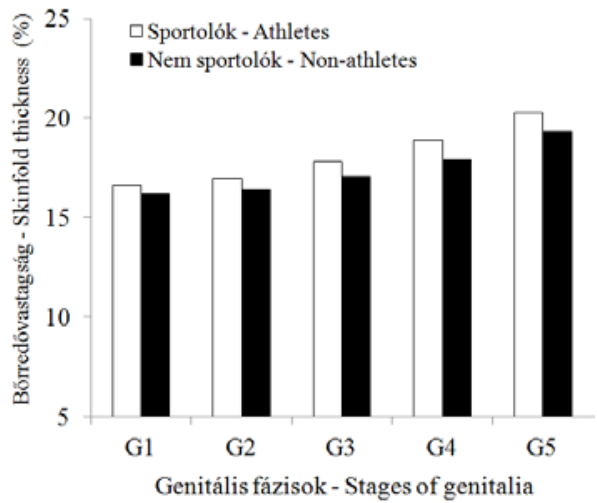

5. ábra: Átlagos relatív bőrredővastagság a mellkason.

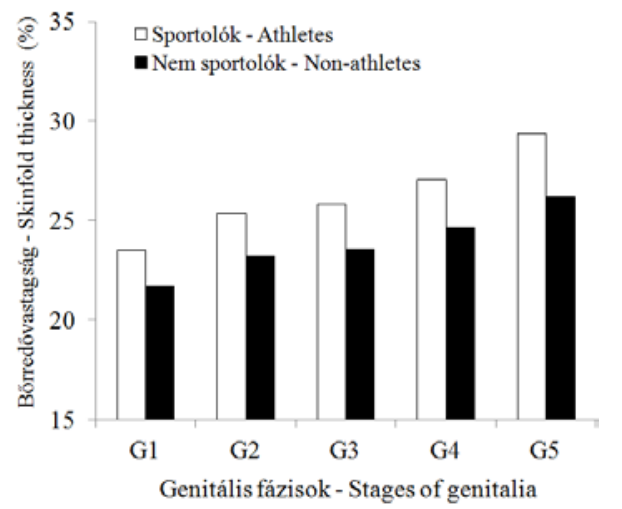

6. ábra: Átlagos relatív bőrredővastagság a medencén.

Fig. 5: Mean relative skinfold thickness on the chest. Fig. 6: Mean relative skinfold thickness on the hip.

A testtáji zsírarányok vizsgálatához szorosan hozzátartozik a törzs üregeiben, a belső szervek között elhelyezkedő zsírszövet is. Ezt a zsír kompartmentet egy - a normál serdülő gyermekekre kidolgozott - regresszió-egyenlettel becsültük (Brambilla és mtsai 2006). A becslés két frakcióra vonatkozik, egyrészt a medence üregében található viszcerális zsírszövet területére, másrészt az abdominális területen a bőr alatt elhelyezkedő zsírszövetre. Ez a kompartment egyaránt magában foglalja a felületes és a mélyen elhelyezkedő szubkután zsírszövetet (Norgan 1997, Shen és mtsai 2003).

A bőr alatt felhalmozott abdominális szubkután zsírszövet az 1. táblázat adatai szerint az érés ideje alatt mind a sportoló, mind a nem sportoló fiúknál gyarapodik. A fokozatok átlagai között szignifikáns különbséget csak a sportolóknál találtunk a közép pubertástól (G3). A zsigeri zsírszövet esetében a tendencia hasonlónak bizonyult. A serdülés kezdetén a sportoló fiúk átlagai kisebbek voltak, de a genitális fejlődés végére beérték a nem sportolókat. Meg kell említeni az irodalmi adatok esetében is közölt jelentős variabilitást (Fox és mtsai 1993, Goran és Gower 1999, Goran és mtsai 1995), amit a szórás értékek hüen tükröztek.

A genitális fejlődésnek és a sporttevékenységnek a hatását a regionális zsírmegoszlásra többváltozós varianciaanalízissel (MANOVA, 2. táblázat) vizsgáltuk. A függő változók közé a rendelkezésre álló paraméterek közül a végtagokon, valamint a törzsön felhalmozott szubkután zsírszövetet, a viszcerális zsírszövetet és a zsírtömeget választottuk.

A lineáris modell illeszkedése megfelelő volt. Ezt többváltozós tesztekkel (Pillai's Trace, Wilks Lambda) és a vizsgált és becsült csoportátlagok összevetésével ellenőriztük.

A teljes modellre vonatkozó eredményeket a korrigált modell sorok tartalmazzák. A parciális eta a szexuális érésnek és a sporttevékenységnek, azaz a modell független változóinak, illetve a közöttük lévő kölcsönhatásnak a magyarázó erejét mutatja. 
1. táblázat. A bör alatti és a zsigeri abdominális zsírszövet területe $\left(\mathrm{cm}^{2}\right)$ a genitális fokozatok szerint. Table 1 . The area of the subcutaneous and visceral abdominal adipose tissue $\left(\mathrm{cm}^{2}\right)$ by the stages of genital development.

\begin{tabular}{|c|c|c|c|c|}
\hline Genitális fokozat & Sportolók & - Athletes & & Nem sportolók - Non-athletes \\
\hline Genital stages & Átlag - Mean & Szórás - SD & $\mathrm{p} \leq 0,05$ & Átlag - Mean Szórás - SD \\
\hline
\end{tabular}

\begin{tabular}{|c|c|c|c|c|c|}
\hline & \multicolumn{5}{|c|}{ Bör alatti abdominális zsírszövet - Subcutan abdominal adipose tissue } \\
\hline G1 & 68,02 & 45,25 & * & 85,07 & 76,42 \\
\hline G2 & 81,31 & 49,16 & * & 101,02 & 88,37 \\
\hline G3 & $101,96^{+}$ & 49,64 & * & 123,02 & 93,24 \\
\hline G4 & $128,37^{+}$ & 45,12 & & 129,32 & 82,23 \\
\hline \multirow[t]{2}{*}{ G5 } & $165,62^{+}$ & 53,40 & & 153,76 & 82,53 \\
\hline & \multicolumn{5}{|c|}{ Zsigeri abdominális zsírszövet - Visceral abdominal adipose tissue } \\
\hline G1 & 15,31 & 6,57 & * & 17,22 & 10,26 \\
\hline G2 & $19,37^{+}$ & 7,30 & * & $21,45^{+}$ & 11,99 \\
\hline G3 & $22,78^{+}$ & 6,99 & & 24,93 & 12,41 \\
\hline G4 & $26,21^{+}$ & 5,78 & & 26,68 & 10,86 \\
\hline G5 & $31,07^{+}$ & 5,88 & & 30,41 & 11,48 \\
\hline
\end{tabular}

${ }^{+}$: szignifikáns különbség a jelzett és az azt megelőző fokozat átlagértékei között - significant difference between the means of the signed and the preceding stage; *: szignifikáns különbség a sportolók és nem sportolók között - significant difference between athletes and non-athletes

2. táblázat. A genitális fejlődés és a sporttevékenység regionális zsírmegoszlásra gyakorolt hatásának vizsgálatára elvégzett többváltozós varianciaelemzés eredményei.

Table 2. The results of multivariate analysis of variance carried out to study the influence of genital maturation and sport activity on regional fat distribution.

\begin{tabular}{|c|c|c|c|}
\hline Függő változó - Dependent variable & $\mathrm{F}$ & $\mathrm{p}$ & Parciális eta - Partial eta \\
\hline \multicolumn{4}{|l|}{ Korrigált modell - Corrected model } \\
\hline Végtagzsír - Extremity fat (mm) & 34,306 & $<0,001$ & 0,148 \\
\hline Törzszsír - Trunk fat (mm) & 8,418 & $<0,001$ & 0,041 \\
\hline Zsigeri zsír - Visceral fat $\left(\mathrm{cm}^{2}\right)$ & 64,607 & $<0,001$ & 0,247 \\
\hline Zsírtömeg - Body fat mass (kg) & 24,391 & $<0,001$ & 0,110 \\
\hline \multicolumn{4}{|l|}{ Genitális fejlödés - Genital maturation } \\
\hline Végtagzsír - Extremity fat (mm) & 9,077 & $<0,001$ & 0,020 \\
\hline Törzszsír - Trunk fat (mm) & 3,728 & 0,005 & 0,008 \\
\hline Zsigeri zsír - Visceral fat $\left(\mathrm{cm}^{2}\right)$ & 125,704 & $<0,001$ & 0,221 \\
\hline Zsírtömeg - Body fat mass (kg) & 37,204 & $<0,001$ & 0,077 \\
\hline \multicolumn{4}{|l|}{ Sporttevékenység - Sport activity } \\
\hline Végtagzsír - Extremity fat (mm) & 216,219 & $<0,001$ & 0,109 \\
\hline Törzszsír - Trunk fat (mm) & 63,079 & $<0,001$ & 0,034 \\
\hline Zsigeri zsír - Visceral fat $\left(\mathrm{cm}^{2}\right)$ & 5,669 & 0,017 & 0,003 \\
\hline Zsírtömeg - Body fat mass (kg) & 92,721 & $<0,001$ & 0,050 \\
\hline \multicolumn{4}{|c|}{ Genitális fejlödés $\times$ Sporttevékenység - Genital maturation $\times$ Sport activity } \\
\hline Végtagzsír - Extremity fat (mm) & 1,234 & 0,294 & 0,003 \\
\hline Törzszsír - Trunk fat (mm) & 0,869 & 0,482 & 0,002 \\
\hline Zsigeri zsír - Visceral fat $\left(\mathrm{cm}^{2}\right)$ & 2,008 & 0,091 & 0,005 \\
\hline Zsírtömeg - Body fat mass (kg) & 0,489 & 0,744 & 0,001 \\
\hline
\end{tabular}


A modell szignifikánsnak bizonyult. A parciális eta alapján mind a genitáliák fejlődése, mind a sporttevékenység befolyásolja a regionális zsírmegoszlást. A két vizsgált tényező a legerősebb hatást a viszcerális zsírszövetre és a végtagokat borító zsírszövetre fejti ki. A független változók között nem volt interakció.

A genitális fejlödés hatása a testtáji zsírra szignifikáns volt. A parciális eta magyarázó ereje a szubkután törzszsír esetében rendkívül csekélynek bizonyult. A szexuális érés a zsigeri zsírra hatott a legjobban, de befolyása nem volt elhanyagolható a teljes test zsírtartalmára sem. A sporttevékenység a vizsgált testtájak közül a legnagyobb hatást a végtagokat borító zsírszövetre gyakorolta.

\section{Az eredmények megvitatása}

A növekedés során a felnőtt forma kialakulása meghatározott irányok mentén történik. Minden életkori szakasznak megvan a maga jelentősége e formaterv alakításában. A serdülés időszakában megváltozik a tempó, új növekedési, fejlődési irányultságok lépnek müködésbe. A szexuális érés folyamata a szomatikus változások sajátos mintázatával kapcsolódik össze. A legintenzívebb növekedés a hosszúsági, szélességi, kerületi és a tömeg dimenziókban a genitális fejlődés idején, föleg a G3 stádium végén, a G4 stádium első és középső harmadában következik be (Pápai 1999, 2000). A közép pubertás eseményeként megjelenik a spermarche, amely a legintenzívebb testi növekedés szakaszát jelzi. Megváltoznak a szomatotípus komponensek dominanciaviszonyai és átrendeződnek a testösszetevők is (Pápai és mtsai 1994, Bodzsár és Zsákai 2012).

Jelen tanulmányban a zsírszövet változásának mintázatát vizsgáltuk a test különbözö régióiban a genitális fejlődés függvényében. Közismert, hogy a test zsírtartalma a serdülés során sajátos módon változik. A zsírhullámot, azaz a serdülést megelőző zsírakkumulációt, és a felhalmozást követö zsírcsökkenést már a múlt században megfigyelték és leírták (Tanner és Whitehouse 1975, Falkner 1975). A sportoló fiúkra vonatkozó vizsgálatok szerint (Pápai és mtsai 1996/97) a gyarapodás 10 éves korban indul, 12 éves kor körül éri el a csúcsot, ami után először egy hirtelen leszálló, majd egy ellaposodó görbe mentén csökken a test zsírtartalma. Ez a hullám látható az érési fokozatok szerinti elrendezésben is (2. ábra). A zsírgyüjtő szakasz csúcsa egybeesik az első genitális fejlődési stádiummal (G2), leszálló ága végighúzódik a pubertáson. A jelenséget a regionális zsíreloszlás szempontjából szemügyre véve nem tudjuk pontosan, hogy vajon a zsírszövetnek mindegyik összetevője hozzájárul-e a zsírgyarapodáshoz, illetve az utána következö csökkenéshez.

Ez a zsírfelhalmozás a gyermekkor lezárásának és a pubertás nyitányának tekinthető. Azt feltételezzük, hogy az intenzívebb zsírakkumuláció valószínủ feladata a pubertáskori gyors növekedés energiaköltségének fedezése (Pápai és mtsai 2012).

A 2. ábráról az is leolvasható, hogy a serdülés idején a fiúk testének zsírtartalma jelentősen, mintegy 3\%-ot csökken. Vajon mely regionális zsír kompartmentekben bekövetkezö változások idézik elö ezt az eredményt? Adataink szerint az egyes testrégiókban elhelyezkedö szubkután zsírszövetben ellentétes irányú proporcionális változások zajlanak. A végtagokon a zsírszövet arányának csökkenését (3-4. ábra), a törzsön annak emelkedését (5-6. ábra) lehet megfigyelni (Hajňis és mtsai 1989, Bodzsár 1991, 2003, Malina és Bouchard 1991, Pápai 1992). Ez a tendencia a zsírszövet serdülökori változása egyik legjelentősebb eseményének, a zsírszövet ún. centralizációjának (Ridder és mtsai 1992, Lenthe és mtsai 1996, Malina 1986, 1996, 
Taylor és mtsai 1997, Hajňis és mtsai 2003, Toselli és mtsai 2015) a részjelensége. A centrális adipozitás mértéke az életkor előrehaladásával fokozódik (Taylor és munkatársai 1997, Bose 2002).

A lányokra vonatkozó korábbi vizsgálatok azt mutatták, hogy a szexuális érés befejeződésével a raktározott zsírszövet végtagi túlsúlyú (Pápai 2000a, b, Tróznai és Pápai 2005). A sportoló fiúknál jelen adataink szerint a G5 stádiumban a törzset és a végtagokat borító zsírszövet azonosan 50-50\%, míg a nem sportolóknál - a leányokhoz hasonlóan - még végtagi túlsúlyú maradt a szubkután zsír.

A kutatások kevésbé terjedtek ki arra a kérdésre, hogy vajon a különböző testtájakon a változások egymáshoz képest milyen ütemben zajlanak (Malina és mtsai 1999). Megfigyeléseink szerint a genitális fejlődéssel előrehaladva a felső végtagon az alsó végtaghoz viszonyítva nagyobb arányú volt a zsírszövet fogyása. Ugyanakkor a két törzsrégiót összehasonlítva azt találtuk, hogy a zsírakkumuláció nagyobb mérvü volt a medencerégióban, mint a mellkason. A tendencia mind a sportoló, mind a nem sportoló fiúknál megfigyelhető volt. Az adatok azt támasztják alá, hogy a test különböző anatómiai területein nem aránytartóan zajlik a bőr alatti zsírszövet átrendeződése.

Ahhoz, hogy a regionális zsírmegoszlásról teljesebb képet kapjunk, a bőr alatti frakcióban lezajló átalakulások mellett fontos megismeri a zsigeri zsírszövet változását is. $\mathrm{Az}$ 1. táblázatban bemutattuk a regresszió-egyenletek segítségével becsült zsigeri és a szubkután abdominális zsírfrakciók változását a szexuális érés során.

Szerettük volna közös vonatkoztatási keretben vizsgálni a szubkután és a zsigeri zsírszövetre vonatkozó eredményeinket, ezért az abszolút zsírtömeg arányában fejeztük ki a regionális adipozitást jellemző paramétereket. A szubkután régiókat összevontuk, csak a végtagon és a törzsön található zsírszövet vastagságát vettük figyelembe. A nevezőbe a zsírtömeg értékei kerültek (1. ábra).

A 7. ábra azt mutatja, hogy a genitális fejlödés során hogyan változott az $1 \mathrm{~kg}$ testzsírra jutó, a végtagokon található zsírszövet vastagsága. A csökkenés mindkét csoportban szignifikáns volt és az alcsoportok között is jelentős volt az eltérés $(\mathrm{p} \leq 0,05)$. A törzsön lévő zsírszövet közel arányosan változott a testzsírtömeg gyarapodásával (8. ábra). A sportolók és a nem sportolók között ebben a testarányban nem volt különbség.

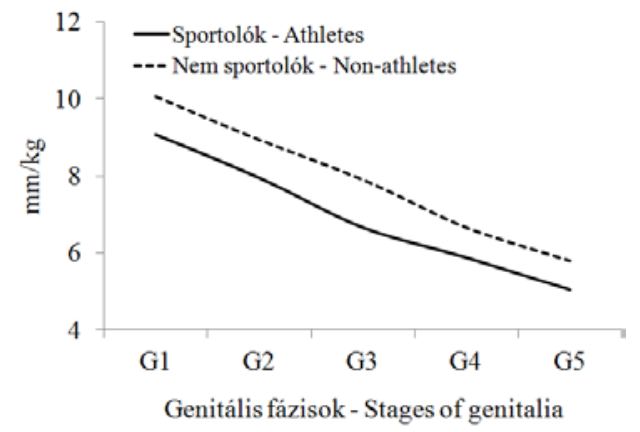

7. ábra: A végtagzsír vastagsága és a zsírtömeg aránya. Fig. 7: The ratio of extremity fat and total fat mass.

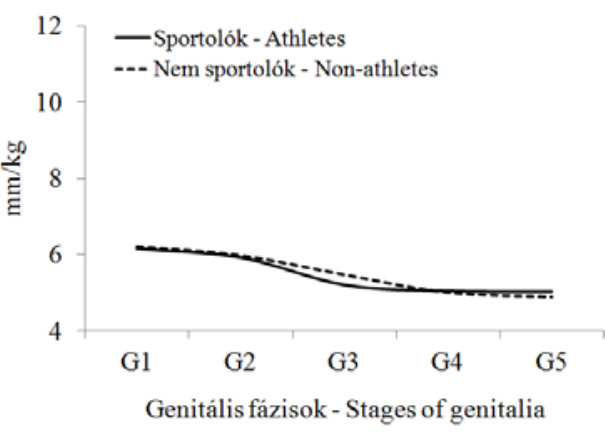

8. ábra: A törzszsír vastagsága és a zsírtömeg aránya. Fig. 8: The ratio of trunk fat and total fat mass.

A 9. ábra a regresszió-egyenlettel becsült bör alatti zsírszövet zsírtömeg egységben kifejezett területét mutatja. Az ábrából kitünik, hogy a G2 stádiumtól a sportolóknál egy 
igen gyors felhalmozás indul, amely meghaladja a testzsírtömeg gyarapodásának ütemét. A nem sportolóknál is megfigyelhető a ráta emelkedése, de az egymást követő fokozatok között nincs szignifikáns különbség $(\mathrm{p}>0,05)$. A bőrredőkből számított és a regresszióegyenlettel kapott, törzsre vonatkozó ráták eltérő változási irányt mutattak. Ennek több oka is lehetséges. Egyrészt a bőrredők mindkét törzsrégiót reprezentálták, míg az abdominális szubkután zsírszövet (SAT) csak az abdominális testtájat, másrészt a medencén a bőrredök segítségével csak a felületes zsírszövet vastagságát tudtuk becsülni, míg a SAT magában foglalta a felületes és mély zsírszövetet is (Norgan 1997, Shen és mtsai 2003).

A medence üregében elhelyezkedő zsírszövet (10. ábra) felhalmozása mindkét csoportban gyorsabb, mint a teljes zsírtömeg akkumulációja. A ráta azt is demonstrálja, hogy a sportolóknál 1 kg zsírtömegre nagyobb zsírterület jut, mint a nem sportolóknál.

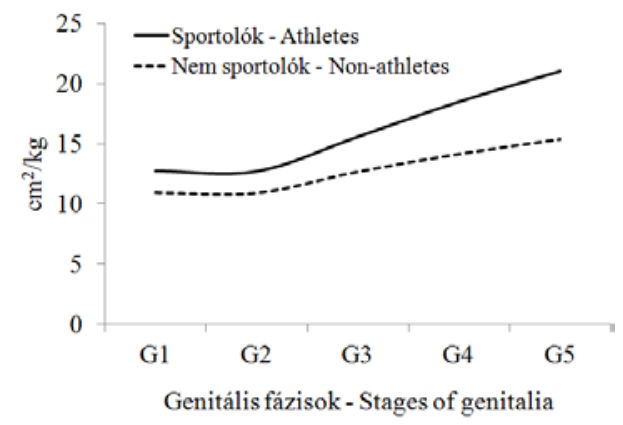

9. ábra: Az abdominális régió bör alatti zsírszövet területének és a zsírtömegnek az aránya.

Fig. 9: The ratio of subcutaneous abdominal adipose tissue area and total fat mass.

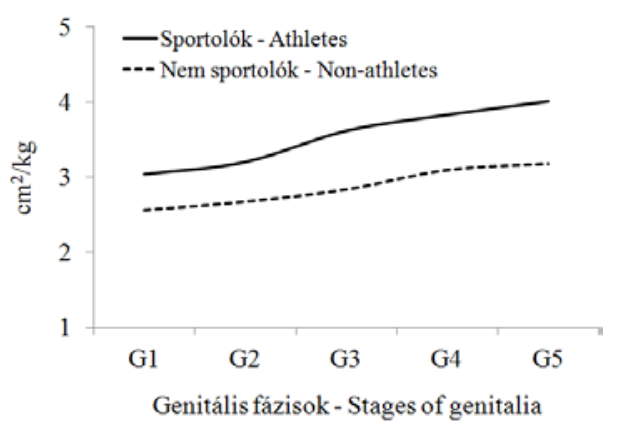

10. ábra: Az intra-abdominalis régió zsírszövet területének és a zsírtömegnek az aránya.

Fig. 10: The ratio of adipose tissue area and total fat mass.

Eredményeinket összegezve megállapítható, hogy a végtagokon és a törzsön az össz testzsír arányában kifejezett bőr alatti zsírszövet az éréssel előrehaladva csökken. A törzs abdominális régiójában viszont mind a zsigeri, mind a bőr alatti zsírszövet gyarapodása túlszárnyalja a testzsírtömeg felhalmozódási ütemét.

Ismerve a testméretek intenzív serdülési növekedési tempóját, a testösszetételben és a testformában bekövetkező jelentős arányváltozást, azt gondolhatnánk, hogy a különböző testrégiókban elhelyezkedö zsírszövetben is a genitális fejlödés (G2-G4) idején zajlanak a legdrámaibb átrendeződések. Ezzel ellentétben a bőr alatt található zsírszövetben a változások a szexuális érés idején kiegyenlítettek voltak. Ez tehát azt jelentené, hogy a genitális fejlődés a szubkután zsírszövet változásában csendes időszakot jelöl. Fontos azonban kiemelni a töréspontokat, azokat az ugrásszerü változásokat, amelyeket elsősorban a genitális fejlődés szakaszhatárain (a G1-G2 és főleg a G4-G5 stádiumok között) lehetett megfigyelni, és amelynek eredményeként a regionális zsírszövet arányaiban átrendeződött: perifériás helyzetüből egyre inkább centrálissá vált. E folyamatban külön kiemelnénk az abdominális zsírszövet jelentőségét, amelynek a bőr alatti és a medence üregében elhelyezkedő kompartmentjei mind abszolúte, mind relatíve gyorsan gyarapodtak, és amelynek anyagcsere tulajdonságai lehetővé teszik a gyorsan változó energiaigény kielégítését és az ahhoz való adaptációt. Úgy tünik, hogy a zsírszövet regionális elrendeződésének megváltozása egyfajta metabolikus átkapcsolást is jelent. A normál gyermekekre vonatkozóan e területen alig áll rendelkezésre irodalmi 
adat. Talán nem véletlen, hogy több kutató hangsúlyozza, hogy a pubertás időszaka kritikus periódus lehet az elhízás szempontjából (Dietz 1994, Lawlor és Chaturvedi 2006). Solorzano és McCartney (2010) szerint a gyermekkorban kialakuló túlsúly befolyásolhatja a serdülőkori fejlődést. Amennyiben a törzsi típusú elhízás már a pubertás előtt fennáll, patogén irányba fordulhat a növekedés és fejlődés, teret adva a metabolikus és kardiovaszkuláris, valamint a daganatos betegségek korai kifejlődésének (Kelly és mtsai 2014).

A sportoló és nem sportoló fiatalok regionális zsírmegoszlását a genitális fejlődés függvényében vizsgálva megállapítható, hogy mindkét csoport esetében hasonló trend érvényesült. Az eltérés abban mutatkozott, hogy a sportolók törzsén arányaiban több volt a szubkután zsírszövet és a medencei régióban nemcsak a bőr alatti, hanem a zsigeri zsír növekedése is intenzívebb volt, mint a nem sportolóknál. A kutatók szerint a törzsön és a törzsben felhalmozódó zsír kevésbé stabil, könnyebben mobilizálható. Jelentősége, hogy ha szükség van rá, gyorsan tud energiát szolgáltatni. Mivel a sportolók energiaszükséglete nagyobb a nem sportolókénál és sokkal gyakoribb náluk a hirtelen gyors energiafelhasználás, valószínü, hogy nagyobb arányban raktároznak azokon az anatómiai helyeken, amelyek jobban megfelelnek energia igényeiknek. Ezek pedig elsősorban a törzsön lévő raktározó helyek. Ez lehet az oka annak is, hogy náluk a centralizáció elörehaladottabb, mint a nem sportolóknál.

Végezetül megvizsgálva a szexuális érés és a sporttevékenység hatását a regionális zsíreloszlásra, azt találtuk, hogy a genitális fejlődés a legnagyobb hatást a viszcerális zsírszövetre gyakorolja, ez a teljes varianciának mintegy egyötödét magyarázza. Lévén a zsigeri zsír erősen hormonérzékeny szerv, ez a hatás nagy valószínüséggel a serdülés során végbemenő jelentős hormonális változásokkal van összefüggésben. A sporttevékenység elsősorban a végtagokon található szubkután zsírszövet vastagságát befolyásolja, a zsigeri zsírra gyakorlatilag nincs hatása.

\section{Összefoglalás}

- A fiúk bőr alatti zsírszövetének regionális megoszlásában a genitális fejlődés ideje alatt jelentős átrendeződések történtek. A zsírszövet a végtagokon folyamatosan csökkent és egyre inkább a törzsre koncentrálódott.

- A medence üregében található zsigeri zsírszövet területe abszolút értékben és arányaiban is megnövekedett.

- E meghatározott irányok mentén történő aránybeli átrendeződést centralizációs tendenciának nevezzük. E folyamat valószínüleg összekapcsolódik az anyag- és energiaforgalom serdülökori változásával.

- Az átalakulás irányvonala a sportolóknál és a nem sportolóknál hasonló volt. A sportolóknál azonban a nem sportolókhoz képest a törzsön és a törzsben is nagyobb volt a zsírszövet aránya. Ez kapcsolatban lehet a normál gyermekekénél nagyobb energiaigénnyel és energiafelhasználással.

- A genitáliák kifejlődése és a zsíreloszlás változása kapcsolatban van egymással. A többváltozós variancia modell szerint a genitális fejlődésnek a zsigeri zsírszövetre van a legnagyobb befolyása.

\section{Irodalom}

Arner, P. (1995): Differences in lipolysis between human subcutaneous and omental adipose tissues. Ann. Med., 27: 435-438. DOI: 10.3109/07853899709002451 
Arner, P. (1997): Regional adipocity in man. J. Endocrinol., 155: 191-192.

Benfield, L.L., Fox, K.R., Peters, D.M., Blake, H., Rogers, I., Grant, C., Ness, A. (2008): Magnetic resonance imaging of abdominal adiposity in a large cohort of British children. Int. J. Obes., 32: 91-99. DOI: 10.1038/sj.ijo.0803780

Blaak, E. (2001): Gender differences in fat metabolism. Curr. Opin. Clin. Nutr., 4: 499-502.

Bodzsár, É.B. (1991): The Bakony Growth Study. Humanbiol. Budapest., 22.

Bodzsár, É.B. (2001): A pubertás auxológiai jellemzői. Humanbiol. Budapest., Suppl. 28.

Bodzsár, É.B. (2003): Életkorok biológiája. A pubertáskor. ELTE Eötvös Kiadó, Budapest.

Bodzsár, É., Zsákai, A. (2004): Humánbiológia. Gyakorlati kézikönyv. ELTE Eötvös Kiadó, Budapest.

Bodzsár, É., Zsákai, A. (2012): Magyar gyermekek és serdülők testfejlettségi állapota Országos Növekedésvizsgálat 2003-2006. Plantin Kiadó, Budapest. p. 240.

Bonora, E., Micciolo, R., Ghiatas, A., Lancaster, J.L., Alyassin, A., Muggeo, M., Defronzo, R.A. (1995): Is it possible to derive a reliable estimate of human visceral and subcutaneous abdominal adipose tissue from simple anthropometric measurements? Metabolism, 44(12): 1617-1625. DOI: 10.1016/0026-0495(95)90084-5

Bose, K. (2002): Age trends in adiposity and central body fat distribution among adult white men resident in Peterborough, East Anglia, England. Coll. Antropol., 26 (1): 179-186.

Brambilla, P., Manzoni, P., Sironi, S., Simone, P., Del Maschio, A., Natale, B., Chiumello, G. (1994): Peripheral and abdominal adiposity in childhood obesity. Int. J. Obes. Relat. Metab. Disord., 18: 795-800.

Brambilla, P., Manzoni, P., Agostini, G., Beccaria, L., Ruotolo, G., Sironi, S., Del Maschio, A., Chiumello, G. (1999): Persisting obesity starting before puberty is associated with stable intraabdominal fat during adolescence. Int. J. Obes. Relat. Metab. Disord., 23: 299-303.

Brambilla, P., Bedogni, G., Moreno, L.A., Goran, M.I., Gutin, B., Fox, K.R., Peters, D.M., Barbeau, P., Simone, M., Pietrobelli, A. (2006): Crossvalidation of anthropometry against magnetic resonance imaging for the assessment of visceral and subcutaneous adipose tissue in children. Int. J. Obesity, 30: 23-30. DOI: 10.1038/sj.ijo.0803163

Chen, C., Chen, Y., Chuang, C., Chiang, L., Chiao, S., Hsieh, K. (2014): The study of anthropometric estimates in the visceral fat of healthy individuals. Nutrit. J., 13: 46-54. DOI: 10.1186/1475-2891-13-46

Daniels, S.R., Morrison, J.A., Sprecher, D.L., Khoury, P., Kimball, T.R. (1999): Association of body fat distribution and cardiovascular risk factors in children and adolescents. Circulation, 99: 541-545. DOI: 10.1161/01.CIR.99.4.541

Despres, J.P., Prud'homme, D., Pouliot, M.C., Tremblay, A.T., Bouchard, C (1991): Estimation of deep abdominal adipose-tissue accumulation from simple anthropometric measurements in men. Am. J. Clin. Nutr.: 54: 471-477.

Dietz, W.H. (1994): Critical periods in childhood for the development of obesity. Am. J. Clin. Nutr., 59: 955-999.

Drinkwater, D.T., Ross, W.D. (1980): Anthropometric fractionation of body mass. In: Ostyn, M., Beunen, G., Simons, J. (Eds) Kinanthropometry II. University Park Press, Baltimore. 178-189.

Eisemann, J.C., Malina, R.M. (2002): Age-related changes in subcutaneous adipose tissue of adolescent distance runners and association with blood lipoproteins. Ann. Hum. Biol., 29(4): 389-397. DOI: $10.1080 / 03014460110092252$

Falkner, F. (1975): Body composition. In: Berenberg, S.R. (Ed.) Puberty. Stenfert Kroese, Leiden. 123-131.

Forbes, G.B. (1978): Body composition in adolescence. In: Falkner, F., Tanner, J.M. (Eds) Human Growth. Vol. 2. Postnatal Growth. Plenum Press, New York - London. 239-272.

Fox, K., Peters, D., Armstrong, N., Sharpe, P., Bell, M. (1993): Abdominal fat deposition in 11year-old children. Int. J. Obes. Relat. Metab. Disord., 17: 11-16.

Garn, S.M., Lavelle, M., Rosenberg, K.L., Hawthorne, V.M. (1986): Maturational timing as a factor in female fatness and obesity. Am. J. Clin. Nutr., 43: 879-883. 
Goran, M.I (1999):Visceral fat in prepubertal children: Influence of obesity, anthropometry, ethnicity, gender, diet, and growth. Am. J. Hum. Biol., 11: 201-207. DOI: 10.1002/(SICI)15206300(1999)11:2<201::AID-AJHB8>3.0.CO;2-R

Goran, M.I., Gower, B.A. (1999): Relation between visceral fat and disease risk in children and adolescents. Am. J. Clin. Nutr., 70(Suppl): 149-156.

Goran, M.I., Kaskoun, M.C., Shuman, W.P. (1995): Intra-abdominal adipose tissue in young children. Int. J. Obes. Relat. Metab. Disord., 19: 279-283.

Goran, M.I., Gower, B.A., Treuth, M., Nagy, T.R. (1998): Prediction of intra-abdominal and subcutaneous abdominal adipose tissue in healthy pre-pubertal children. Int. J. Obesity, 22: 549-558.

Goulding, A., Taylor, R.W., Gold, E., Lewis-Barned, N.J. (1996): Regional body fat distribution in relation to pubertal stage: a dual-energy X-ray absorptiometry study of New Zealand girls and young women. Am. J. Clin. Nutr., 64(4): 546-551.

Guo, S.S., Chumlea, W.C., Roche, A.F., Siervogel, R.M. (1998): Age and maturity related changes in body composition during adolescence into adulthood: the Fels longitudinal study. Appl. Radiat. Isotopes, 49: 581-585. DOI: 10.1016/S0969-8043(97)00190-5

Gutin, B., Johnson, M.H., Humphries, M.C., Hatfield-Laube, J.L., Kapuku, G,K,, Allison, J.D., Gower, B.A., Daniels, S.R., Barbeau, P. (2007): Relationship of visceral adiposity to cardiovascular disease risk factors in black and white teens. Obesity, 15: 1029-1035. DOI: 10.1038/oby.2007.602

Hajňis, K., Blažek, V., Břutek, J. (1989): The age related changes in the distribution of subcutaneous fat in Czech and Slovak children. In: Hajňis, K. (Ed.) Growth and Ontogenetic Development in Man. Vol. III. Charles University, Prague. 3-23.

Hajňis, K., Pařízková, J., Petrásek, R. (2003): Development of centrality indices of subcutaneous fat during growth. Coll. Antropol., 27: 563-571.

He, Q., Horlick, M., Thorton, J., Wang, J., Pierson, R.N., Heshka, S., Gallagher, D. (2004): Sexspecific fat distribution is not linear across pubertal groups in a multiethnic study. Obes. Res., 12: 725-733. DOI: 10.1038/oby.2004.85

Huang, T.T., Johnson, M.S., Figueroa-Colon, R., Dwyer, J.H., Goran, M.I. (2001): Growth of visceral fat, subcutaneous abdominal fat, and total body fat in children. Obes Res., 9: 283-289. DOI: $10.1038 /$ oby.2001.35

Karastergiou, K., Smith, S.R., Greenberg, A.S., Fried, S.K. (2012): Sex differences in human adipose tissues - the biology of pear shape. Biol. Sex Diff., 3(1): 1-10. DOI: 10.1186/2042$\underline{6410-3-13}$

Kay, S.J., Singh, M.A.F. (2006): The influence of physical activity on abdominal fat: a systematic review of the literature. Obes. Rev., 7: 183-200. DOI: 10.1111/j.1467-789X.2006.00250.x

Kekes-Szabo, T., Hunter, G.R., Nyikos, I., Nicholson, C., Snyder, S., Berland, L. (1994): Development and validation of computed tomography derived anthropometric regression equations for estimating abdominal adipose tissue distribution. Obes. Res., 2: 450-457. DOI: 10.1002/j.1550-8528.1994.tb00092.x

Kelley, D.E., Thaete, F.L., Troost, F., Huwe, T., Goodpaster, B.H., (2000): Subdivisions of subcutaneous abdominal adipose tissue and insulin resistance. Am. J. Physiol. Endocrinol. Metab., 278: 941-948.

Kelly, A.S., Dengel, D.R., Hodges, J., Zhang, L., Moran, A., Chow, L., Sinaiko, A.R., Steinberger, J. (2014): The relative contributions of the abdominal visceral and subcutaneous fat depots to cardiometabolic risk in youth. Clin. Obes., 4(2): 101-107. DOI: 10.1111/cob.12044

Lawlor, D.A., Chaturvedi, N. (2006): Treatment and prevention of obesity - are there critical periods for intervention? Int. J. Epidemiol., 35: 3-9. DOI: 10.1093/ije/dyi309

Lenthe, F.J., Kemper, H.C.G., Van Mechelen, W., Twisk, J.W.R.. (1996): Development and tracking of central patterns of subcutaneus fat in adolescence and adulthood: the Amsterdam Growth and Health Study. Int. J. Epidemiol., 25: 1162-1171. DOI: 10.1093/ije/25.6.1162 
Malina, R.M. (1986): Maturational considerations in elite young athletes. In: Day. J.A.P. (Ed.) Perspectives in Kinanthropometry. Human Kinetics, Champaign, Illinois. 29-44.

Malina, R.M. (1996): Regional body composition: age, sex, and ethnic variations. In: Roche, A.F., Heymsfield, S.B., Lohman, T.G. (Eds) Human body composition. Human Kinetics. 217-229.

Malina, P.M., Bouchard, C. (1991): Growth, maturation and physical activity. Human Kinetics, Champaign. 251-272.

Malina, R.M., Koziel, S., Bielicki, T. (1999): Variation in subcutaneous sdipose tissue distribution associated with age, sex, and maturation. Am. J. Hum. Biol., 11: 189-200. DOI: 10.1002/(SICI)1520-6300(1999)11:2<189::AID-AJHB7>3.0.CO;2-\#

Manolopoulos, K.N., Karpe, F., Frayn, K.N. (2010): Gluteofemoral body fat as a determinant of metabolic health. Int. J. Obes., 34: 949-959. DOI: $10.1038 / \mathrm{ijo.2009.286}$

Martin, R., Saller, K. (1957/1966): Lehrbuch der Anthropologie. 3. Band. Fischer, Stuttgart.

Mitova, Z., Mladenova, S. (2014): Anthropometric assessment of sub-cutaneous and visceral adipose tissue in children and adolescents from Sofia and Smolyan (Bulgaria). Mediterr. J. Soc. Sci., 5(1): 369-376. DOI: 10.5901/mjss.2014.v5n1p369

Mueller, W.H. (1982): The changes with age of the anatomical distribution of fat. Soc. Sci. Med., 16: 191-196. DOI: $10.1016 / 0277-9536(82) 90022-3$

Norgan, N.G. (1997): The beneficial effects of body fat and adipose tissue in humans. Int. J. Obes., 21: 738-746.

Owens, S.G., Gutin, B., Allison, J., Thompson, W. (1999): Effect of physical training on total and visceral fat in obese children. Med. Sci. Sport. Exer., 31(1): 143-148. DOI: 10.1097/00005768-199901000-00022

Pápai, J.(1992): Jászsági 7-14 éves gyermekek növekedése, testi fejlödése és fizikai teljesítménye. Kandidátusi értekezés. ELTE, Budapest.

Pápai, J. (1999): Pubertal growth and maturation in athletic boys. Anthrop. Közl., 40: 63-69.

Pápai, J. (2000a): Sexual maturation and body composition in athletic boys. In: Bodzsár, É.B., Susanne, C., Prokopec, M. (Eds) Puberty: Variability of Changes and Complexity of Factors. Eötvös Univ. Press, Budapest. 83-94.

Pápai, J. (2000b): Utánpótláskorúak testösszetétel és szomatotípus különbségei eredményességi szintjük függvényében. Magyar Sporttudományi Szemle, Különszám (Kutatási beszámoló 1997-1999): 57-61.

Pápai, J., Bodzsár, É.B., Szabó, T. (1994): Mass fractions, somatotype and maturity status in athletic boys. Auxology '94. Humanbiol. Budapest., 25: 515-519.

Pápai, J., Szmodis, I., Szabó, T. (1996/97): Changes in body fat during puberty in athletic boys. Anthrop. Közl., 38: 75-80.

Pápai, J., Tróznai, Zs., Szabó, T., Szabó, A. (2012): Fat pattern of athlete and non-athlete girls during puberty. Anthropol. Rev., 75: 41-50. DOI: 10.2478/v10044-012-0003-5

Ramos-Ibanez, N. (2009): Intra-abdominal adipos tissue: growth, asseessment and association with the development of metabolic alterations in children and adolescents. Biol. Med. Hosp. Infant. Mex., 66: 492-501.

Ribeiro, J., Santos, P., Duarte, J., Mota, J. (2006): Association between overweight and early sexual maturation in Portuguese boys and girls. Ann. Hum. Biol., 33: 55-63. DOI: $\underline{10.1080 / 00207390500434135}$

Ridder, C.M., Thijssen, J.H.H., Bruning, P.F., van den Brande, J.L. (1992): Body fat mass, body fat distribution, and pubertal development: A longitudinal study of physical and hormonal sexual maturation of girls. J. Clin. Endocr. Metab., 75: 442-446. DOI: 10.1210/jcem.75.2.1639945

Sbarbati, A., Accorsi, D., Benati, D., Marchetti, I.L., Orsini, G., Rigotti, G., P. Panettiere G.P. (2010): Subcutaneous adipose tissue classification. Eur. J. Histochem., 54: 226-230. DOI: 10.4081/ejh.2010.e48

Scafoglieri, A., Clarys, J.P., Cattrysse, E., Bautmans, I. (2014): Use of anthropometry for the prediction of regional body tissue distribution in adults: Benefits andlimitations in clinical practice. Aging Dis., 5(6): 373-393. DOI: 10.14366/AD.2014.0500373 
Shen, W., Wang, Z., Punyanita, M., Lei, J., Sinav, A., Kral, J.G., Imielinska, C., Ross, R., Heymsfield, S.B. (2003): Adipose tissue quantification by imaging methods: A proposed classification. Obes. Res., 11(1): 5-16. DOI: 10.1038/oby.2003.3

Slentz, C.A., Houmard, J.A., Kraus, W.E. (2009): Exercise, abdominal obesity, skeletal muscle, and metabolic risk: Evidence for a dose response. Obesity, 17: S27-S33. DOI 10.1038/oby.2009.385

Solorzano, C.M.B., McCartney, C.R. (2010): Obesity and the pubertal transition in girls and boys. Reproduction, 140: 399-410. DOI: 10.1530/REP-10-0119

Tanner, J.M. (1962): Growth at adolescence. 2nd Edition. Blackwell, Oxford.

Tanner, J.M., Hiernaux, J., Jarman, S. (1969): Growth and physique studies. In: Weiner, J.S., Lourie, J.A. (Eds) Human Biology. A guide to field methods. International Biological Programme Handbook 9. Blackwell, Oxford - Edinburgh. 1-76.

Tanner, J.M., Whitehouse, R.H., (1975): Revised standards for triceps and subscapular skinfolds in British children. Arch. Dis. Childh., 50: 142-145. DOI: 10.1136/adc.50.2.142

Taylor, R.W., Gold, E., Manning, P., Goulding. A. (1997): Gender differences in body fat content are present well before puberty. Int. J. Obes., 21: 1082-1084.

Toselli, S., Di Michele, R., Jürimäe, T., Brasili, P. (2015): Body fat distribution in Italian, Spanish and Estonian children. J. Adv. Nutr. Hum. Metab., 2: 1-8.

Trayhurn, P., Beattie, J.H. (2001): Physiological role of adipose tissue: white adipose tissue as an endocrine and secretory organ. Proc. Nutr. Soc., 60: 329-339. DOI: 10.1079/PNS200194

Treuth, M.S., Hunter, G.R., Figueroa-Colon, R., Goran, M.I. (1998): Effects of strength training on intra-abdominal adipose tissue in obese prepubertal girls. Med. Sci. Sport. Exer., 30(12): 17381743. DOI: $10.1097 / 00005768-199812000-00013$

Tróznai, Zs., Pápai, J. (2005): Sportoló leányok testtáji zsírmegoszlása. In: Mónus, A. (Szerk.) IV. Országos Sporttudományi Kongresszus. II. Magyar Sporttudományi Társaság, Budapest. 71-79.

Wells, J.C.K. (2010): The evolutionary biology of human body fatness. University Press, Cambridge. 92-11.

Wells, J.C.K. (2012): The evolution of human adiposity and obesity: where did it all go wrong? Dis. Mod. Mechanism., 5: 595-607. DOI: 10.1242/dmm.009613

Wronska, A., Kmiec, Z. (2012): Structural and biochemical characteristics of various white adipose tissue depots. Acta Physiol., 205(2): 194-208. DOI: 10.1111/j.1748-1716.2012.02409.x

Levelezési cím:

Pápai Júlia

Mailing address:

Testnevelési Egyetem, Teljesítmény-élettani Laboratórium

Istvánmezei út 1-3.

H-1146 Budapest

Hungary

papaijulia7@gmail.com 